\title{
Microstructure of skeletal muscles of growing calves fed silage-based vs hay-based diets. I. Fibre diameters
}

\author{
B Kłosowski 1, ${ }^{* \star}$ K Bidwell-Porębska 2,

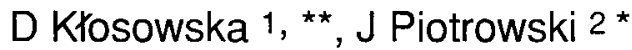 \\ ${ }^{1}$ Meat and Fat Research Institute, Warsaw, Laboratory of Meat Science, Bydgoszcz; \\ ${ }^{2}$ Polish Academy of Sciences, Institute of Genetics and Animal Breeding, \\ Jastrzebiec, 05-551 Mroków, Poland
}

(Received 15 October 1990; accepted 22 October 1991)

\begin{abstract}
Summary - Samples of musculus longissimus dorsi, semimembranosus and semitendinosus were obtained post-slaughter from 2-week, 3-month and 10-month-old bull calves. The 2-week-old calves were fed milk only. All the remaining animals were fed grass silage or hay ad lib and a restricted amount of concentrate from 2 weeks of age onwards. Muscle fibres were differentiated according to Ziegan into fast-twitch glycolytic, fast-twitch oxidoglycolytic and slow-twitch oxidative fibres (FTG, FTO and STO, respectively). In all calves, marked fibre growth took place between 3 and 10 months of age. From the 2nd week to the 3rd month, growth was observed virtually only in the FTG fibres, irrespective of feeding. Feeding calves with a silage-based vs hay-based diet resulted in thicker muscle fibres for each type of fibre. Significant linear regression coefficients have shown the fibre diameters to be clearly related to live weight gain resulting from DM intake that was higher in the silage-based diet.
\end{abstract}

calf / skeletal muscle fibre / silage / hay

Résumé - Microstructure des muscles squelettiques chez les veaux à l'ensilage ou au foin. I. Diamètre des fibres musculaires. Après l'abattage de veaux âgés de 2 semaines, de 3 mois et de 10 mois on a prélevé des échantillons de muscles : longissimus dorsi, semimembranosus et semitendinosus. Les veaux âgés de deux semaines ont été nourris au lait. Les veaux restants recevaient de l'ensilage d'herbe ou du foin à volonté et une quantité limitée de concentré. D'après la méthode de Ziegan (1979) on a distingué des fibres musculaires glycolytiques et oxydatives glycolytiques à contraction rapide (FTG et FTO) et des fibres oxydatives à contraction lente (STO). Chez tous les taurillons de 3 à 10 mois, on a constaté l'augmentation rapide du diamètre des fibres musculaires, mais chez les animaux de 2 semaines à 3 mois, on a observé seulement l'augmentation du diamètre des fibres FTG, indépendamment du régime alimentaire. Les fibres musculaires étaient plus épaisses chez les veaux nourris à l'ensilage que chez ceux nourris au foin. Les coeffi-

* Correspondence and reprints

"* Present address: Technical and Agricultural University, Faculty of Animal Science, Mazowiecka 28, 85-084 Bydgoszcz, Poland 
cients significatifs de la régression linéaire indiquent que le diamètre des fibres musculaires est lié à la vitesse d'accroissement du poids vif des animaux analysés. C'est le résultat d'une ingestion plus grande de matière sèche par les animaux à l'ensilage.

veau / fibre musculaire / ensilage / foin

\section{INTRODUCTION}

Animal growth is influenced by genetic and nutritive factors (Breewinkle et al, 1979; Seideman and Crouse, 1986). Increasing age and increase in live weight are accompanied by an increase in muscle fibre diameter and changes in the percentage of enzymatically differentiated fibre types (Kłosowski et al, 1988). Basically, skeletal muscles are composed of white (fasttwitch glycolytic, FTG), red (slow-twitch oxidative, STO) and intermediate (fast-twitch oxidoglycolytic, FTO) fibres. The thinnest fibres are generally the STO and FTO, whereas the FTG are the thickest. Thus within a given muscle the proportion between individual fibre types may affect both its size and metabolism. There are inter-individual and inter-muscle differences in the distribution of different fibre types, as well as their share in the total muscle weight. Kłosowski and Kłosowska (1984) and Kłosowski et al (1988) reported that the faster the animals' growth as affected by feeding, the larger the fibre diameter and higher the percentage of FTG fibers. In growing calves reared on hayfree low-concentrate diets based on grass silage, satisfactory gains have been reported (Marsh, 1975, 1976; Bartholomew et al, 1981; Bidwell-Porębska et al, 1987; Piotrowski et al, 1988) with no simultaneous mention of any detrimental effect on the animals' health. However, Rumsey et al (1987) found differences in carcass characteristics (lean score for colour, firmness and shrinkage, fat over the ribeye, longissimus muscle area, estimated kid- ney, pelvic and heart fat, USDA yield grade and USDA quality grade) between steers fattened on concentrate-based vs silage-only diets. Moreover, Pellegrini et al (1982) have reporting results obtained in 3 animals only, and suggested that feeding heifers exclusively on maize silage led to myopathia and muscular dystrophy. Investigations presented here constitute an attempt at evaluating the possible relation between diet and fibre diameter in different muscles of growing calves.

\section{MATERIAL AND METHODS}

\section{Animals}

The data were collected on 25 Polish Friesian bull calves born in the autumn and reared during the winter months. All the animals were brought to the Jastrzebiec Experimental Farm at the age of approximately 10 days, and placed in a heated, old-fashioned calf-shed. Until the calves reached 14 days of age, milk only was provided ( $10 \%$ live weight). On day 14,5 randomly selected calves (henceforth referred to as "newborn" calves) were slaughtered and muscle tissue samples were taken. The remaining 20 calves received $300 \mathrm{~g}$ of concentrate daily, with milk provided as before. On the 42nd day of life, the calves were weaned and the daily concentrate allowance was increased to $1000 \mathrm{~g} / \mathrm{head}$. This level of concentrate feeding was maintained until the age of 91 days. Vitamin and mineral mixtures (Polfamix ${ }^{\circledR}$ and Tetamix ${ }^{\circledR}$, Polfa, Poland) were added to the concentrate according to the manufacturer's instructions.

On day 14 , the calves were randomly assigned to one of the following groups: group I: meadow hay cut into $3-5-\mathrm{cm}$ long chaff; group 
II: grass silage prepared with Acidol II (acetic, sulphuric, phosphoric acid and water, 16:1:1:2, $4 \mathrm{~kg} / \mathrm{ton}$ of fresh material).

Silage or hay were provided at libitum until day 91 , when 5 calves from each group were slaughtered and muscle tissue samples were taken. These animals are henceforth referred to as "younger" calves.

The remaining animals, henceforth referred to as "older" calves, still received $1000 \mathrm{~g} / \mathrm{h}$ ead of concentrate per day. Silage or hay were again offered ad libitum, as follows: group la (2nd half of group I), natural length meadow hay until slaughter; group lla (2nd half of group II), grass silage prepared with Acidol II until the 5th month, and then maize silage until slaughter.

Animals from group I and la will henceforth be referred to as hay diet (HD) fed, and those from groups II and Ila as silage diet (SD) fed calves.

The older calves were slaughtered and muscle samples were taken at approximately $250 \mathrm{~kg}$ (242-256) live weight ( $L W$ ). This meant that due to the different daily weight gains, animals from group la were slaughtered at an average age of 338 days (325-350) and those from group lla at 305 days (298-309). However, 2 calves from group Ila died before reaching the weight of 250 $\mathrm{kg}$ - one broke a leg, the other did not survive an acute bloat. Thus the results refer to 5 animals in group la and only 3 in group Ila.

\section{Muscle sampling and preparation}

The following muscies were sampled: musculus longissimus dorsi (LD) from the lumbar region, at the level of the processus transversus of $L 2$, $m$ semimembranosus (SM) and $m$ semitendinosus (ST) from the medial portion. Single tissue samples were taken from all the slaughtered calves (right side of carcass) approximately $1 \mathrm{~h}$ post-mortem and were immediately frozen in liquid nitrogen and sectioned in a cryostat. Ten- $\mu \mathrm{m}$ thick sections were subjected to double reaction for activity of NADH tetrazolium oxidoreductase and myosin ATPase after acid preincubation (Ziegan, 1979). Sections were stained with hematoxylin - eosin according to Van Gieson (Dubowitz et al, 1973). Fast-twitch glycolytic (FTG), slow-twitch oxidative (STO) and fast-twitch oxidoglycolytic (FTO) fibres were obtained as light brown, dark brown and blue, respectively. The smallest diameters (Brooke, 1970) of fibres belonging to each type were determined by measuring 200 fibres/muscle/animal on a lanameter. Moreover, the muscle tissues were carefully examined for the presence of any pathologies.

\section{Statistics}

A $t$-way analysis of variance was applied using the least-squares method. The relationship between LW gains and fibre diameter was estimated by the linear regression as:

$$
y=\mu+\beta(x-\bar{x})
$$

where: $y=$ expected mean fibre diameter;

$\mu=$ mean fibre diameter;

$\beta=$ regression coefficient;

$x=$ obtained $L W$ gain;

$\bar{x}=$ mean $L W$ gain.

Daily LW gains and corresponding fibre diameters were arranged pairwise and analysed with no reference to feeding system or age at slaughter. Moreover, the relationship between fibre diameter and daily gains was examined as related to age, feeding system and interaction between the two. Daily LW gains were calculated from 14 or 42 days (weaning) of age.

\section{RESULTS}

\section{Intake and $L W$ gains}

An attempt at eliminating the effect of the milk feeding period was made by presenting live weight gains not only for the entire experimental period ( 14 days to slaughter), but also within the weight range of 42 days to slaughter.

The LW gains in both younger and older animals were higher in SD fed than in HD fed calves (table I). This corresponds to higher dry matter (DM) intake in animals kept on SD. As the concentrate offered at 
Table I. Mean daily intake and daily live weight (LW gains).

\begin{tabular}{|c|c|c|c|c|}
\hline \multirow[t]{2}{*}{ Age range } & \multicolumn{2}{|c|}{ Younger calves } & \multicolumn{2}{|c|}{ Older calves } \\
\hline & $H D$ fed & SD fed & $H D$ fed & SD fed \\
\hline \multicolumn{5}{|c|}{14 days of age till slaughter } \\
\hline LW gain $(\mathrm{g})$ & 447 & 506 & 617 & 713 \\
\hline Intake DM (g/day) & 1003 & 1155 & 3075 & 4599 \\
\hline $\mathrm{CP}$ (g/day) & 205 & 233 & 501 & 478 \\
\hline GE (MJ/day) & 18.5 & 22.0 & 59.5 & 86.9 \\
\hline $\mathrm{CP} / \mathrm{GE}$ & 11.1 & 10.6 & 8.4 & 5.5 \\
\hline \multicolumn{5}{|c|}{42 days of age till slaughter } \\
\hline LW gain $(g)$ & 393 & 534 & 617 & 736 \\
\hline Intake DM (g/day) & 1140 & 1391 & 3279 & 4944 \\
\hline $\mathrm{CP}(\mathrm{g} / \mathrm{day})$ & 222 & 265 & 532 & 510 \\
\hline GE (MJ/day) & 19.4 & 24.8 & 63.6 & 94.3 \\
\hline $\mathrm{CP} / \mathrm{GE}$ & 11.5 & 10.7 & 8.4 & 5.4 \\
\hline
\end{tabular}

a strictly limited level was always fully consumed, the difference in DM intake reflects the consumption of forages.

In the younger calves the intake of crude protein (CP) and gross energy (GE) was also slightly higher in the SD fed group. In the older animals the daily intake of GE was considerably higher, while the intake of $\mathrm{CP}$ was lower in the SD than in the HD fed group (table I). This was caused by introducing maize silage in the place of grass silage at the age of 5 months, which of course, also affected the CP/GE ratio (g CP/1 MJ GE).

\section{Fibre diameter}

In all SD fed calves (pooled data for younger and older calves) the mean fibre diameters were always higher by $2-5 \mu \mathrm{m}$ than those found in all (similarily pooled) HD fed animals (tables II-IV). According to a 1-way analysis of variance, these differences appeared non-significant only for FTO and both oxidative fibres $(\mathrm{BO})$ in SM muscle (table III). Differences between the feeding systems in younger calves showed a pattern identical to that observed in older animals (tables II-IV), being nonsignificant for FTG in all muscles, and also for FTO in LD and STO in SM muscle. For BO fibres, the effect of the feeding system was found to be significant in each of the 2 age groups considered.

Similarly, a 1-way analysis of variance indicated that all younger calves (pooled data for SD and HD fed) had mean fibre diameters 12-28 $\mu \mathrm{m}$ smaller (tables II-IV) than the older (similarly pooled) animals; the differences were found to be significant in all muscles and for all types of fibre. The relations between younger calves and newborn calves were less definite. Nevertheless, FTG and STO were found to be thinner and FTO to be thicker in newborn calves (tables II-IV); for STO fibres in both LD and SM muscles the respective differences were not found to be significant.

Since the SD calves had, in almost all cases, significantly greater fibre diameters and higher LW gains than HD fed animals 
Table II. Mean fibre diameters $(\mu \mathrm{m}) \mathrm{m}$ longissimus dorsi. Fibre types: FTG: fast twitch glycolytic; STO: slow twitch oxidative; FTO: fast twitch oxidoglycolytic; BO: both oxidative; AT: all types.

\begin{tabular}{|c|c|c|c|c|c|c|}
\hline Age group and feedin & & FTG & STO & FTO & $B O$ & $A T$ \\
\hline Newborn calves & Milk only & $22.8 \mathrm{ABDE}$ & $20.4 \mathrm{AE}$ & 19.5 ABDE & $20.0 \mathrm{AB}^{\mathrm{ab}}$ & $21.7 \mathrm{ABD}$ \\
\hline Younger calves & $\begin{array}{l}\text { Silage diet } \\
\text { Hay diet }\end{array}$ & $\begin{array}{l}27.7 \mathrm{D} \\
25.5 \mathrm{E}\end{array}$ & $\begin{array}{l}21.7 \mathrm{CE} \\
19.7 \mathrm{C}\end{array}$ & $\begin{array}{l}16.6 \mathrm{D} \\
14.8 \mathrm{E}\end{array}$ & $\begin{array}{l}18.8 \mathrm{D}^{\mathrm{a}} \\
16.8 \mathrm{D}^{\mathrm{b}}\end{array}$ & $\begin{array}{l}21.9^{\mathrm{a}} \\
19.0^{\mathrm{a} D}\end{array}$ \\
\hline Older calves & $\begin{array}{l}\text { Silage diet } \\
\text { Hay diet }\end{array}$ & $\begin{array}{l}49.9 \\
49.4\end{array}$ & $\begin{array}{l}33.6 \mathrm{D} \\
31.7 \mathrm{D}\end{array}$ & $\begin{array}{l}28.1 \\
28.2\end{array}$ & $\begin{array}{l}30.9 \mathrm{E} \\
30.0 \mathrm{E}\end{array}$ & $\begin{array}{l}37.2^{\mathrm{b}} \\
36.5^{\mathrm{b}}\end{array}$ \\
\hline $\begin{array}{l}\text { Total silage diet } \\
\text { fed calves }\end{array}$ & & $38.3 \mathrm{~F}$ & $27.7 \mathrm{~F}$ & $22.6 F$ & $25.6 \mathrm{~F}$ & $30.4 \mathrm{E}$ \\
\hline $\begin{array}{l}\text { Total hay diet } \\
\text { fed calves }\end{array}$ & & $33.4 \mathrm{~F}$ & $24.5 \mathrm{~F}$ & $20.1 \mathrm{~F}$ & $22.1 \mathrm{~F}$ & $26.1 \mathrm{E}$ \\
\hline Total younger calves & & $26.6 \mathrm{AC}$ & $20.6 \mathrm{~B}$ & $15.8 \mathrm{AC}$ & $17.8 \mathrm{AC}$ & $20.5 \mathrm{AC}$ \\
\hline Total older calves & & $49.7 \mathrm{BC}$ & $32.8 \mathrm{AB}$ & $28.1 \mathrm{BC}$ & $30.6 \mathrm{BC}$ & $36.8 \mathrm{BC}$ \\
\hline
\end{tabular}

Within columns, means bearing the same letters differ significantly (capitals $P<0.01$; small letters: $P<0.05$ ).

Table III. Mean fibre diameters $(\mu \mathrm{m})$, $m$ seminebranosus.

\begin{tabular}{|c|c|c|c|c|c|c|}
\hline Age group and feedir & & $F T G$ & STO & FTO & $B O$ & $A T$ \\
\hline Newborn calves & Milk only & $25.7 \mathrm{ABD}^{\mathrm{a}}$ & $19.9 \mathrm{AC}$ & $20.6 \mathrm{ABFG}$ & $20.4 \mathrm{ABF}^{\mathrm{a}}$ & $22.3 \mathrm{ABC}$ \\
\hline Younger calves & $\begin{array}{l}\text { Silage diet } \\
\text { Hay diet }\end{array}$ & $\begin{array}{l}27.9 \mathrm{D} \\
26.6^{\mathrm{a}}\end{array}$ & $\begin{array}{l}19.2 \\
21.8 \mathrm{C}\end{array}$ & $\begin{array}{l}\text { 17.9 DF } \\
\text { 17.2 DG }\end{array}$ & $\begin{array}{l}\text { 18.9 DF } \\
19.5 \mathrm{D}^{\mathrm{a}}\end{array}$ & $\begin{array}{l}21.4^{\mathrm{ac}} \\
22.0^{\mathrm{a}}\end{array}$ \\
\hline Oider calves & $\begin{array}{l}\text { Silage diet } \\
\text { Hay diet }\end{array}$ & $\begin{array}{l}50.8 \\
50.0\end{array}$ & $\begin{array}{l}35.4 \\
35.4\end{array}$ & $\begin{array}{l}28.1 \mathrm{E} \\
32.1 \mathrm{E}\end{array}$ & $\begin{array}{l}32.0 E \\
33.8 \mathrm{E}\end{array}$ & $\begin{array}{l}38.4^{\mathrm{b}} \\
39.3^{\mathrm{b}}\end{array}$ \\
\hline $\begin{array}{l}\text { Total silage diet } \\
\text { fed calves }\end{array}$ & & $38.2 \mathrm{E}$ & $27.7^{a}$ & 23.4 & 26.0 & $31.8 \mathrm{D}$ \\
\hline $\begin{array}{l}\text { Total hay diet } \\
\text { fed calves }\end{array}$ & & $34.9 \mathrm{E}$ & $26.8^{a}$ & 23.0 & 25.0 & $28.8 \mathrm{D}$ \\
\hline Total younger calves & & $27.3 \mathrm{AC}$ & $20.6 \mathrm{~B}$ & $17.5 \mathrm{AC}$ & $19.2 \mathrm{AC}$ & $21.8 \mathrm{AC}$ \\
\hline Total older calves & & $50.5 \mathrm{BC}$ & $35.4 \mathrm{AB}$ & $29.6 \mathrm{BC}$ & $32.7 \mathrm{BC}$ & $38.8 \mathrm{BC}$ \\
\hline
\end{tabular}

Within columns, means bearing the same letters differ significantly (capitals: $P<0.01$; small letters: $P<-0.05$ ). Abbreviations explained in table II. 
Table IV. Mean fibre diameters $(\mu \mathrm{m}), \mathrm{m}$ semitendinosus.

\begin{tabular}{|c|c|c|c|c|c|c|}
\hline \multicolumn{2}{|c|}{ Age group and feeding } & $F T G$ & STO & FTO & $B O$ & $A T$ \\
\hline Newborn calves & Milk only & 24.9 ABDE & 20.0 ABEF & $20.6 \mathrm{ABFG}$ & $20.1 \mathrm{AB}$ & $21.6 \mathrm{AB}$ \\
\hline Younger calves & $\begin{array}{l}\text { Silage diet } \\
\text { Hay diet }\end{array}$ & $\begin{array}{l}26.8 \mathrm{D} \\
26.7 \mathrm{E}\end{array}$ & $\begin{array}{l}21.5 \mathrm{E} \\
21.5 \mathrm{~F}\end{array}$ & $\begin{array}{l}\text { 18.5 DF } \\
\text { 17.8 DG }\end{array}$ & $\begin{array}{l}20.1 \mathrm{D} \\
19.5 \mathrm{D}\end{array}$ & $\begin{array}{l}22.0 \mathrm{D} \\
21.8 \mathrm{D}\end{array}$ \\
\hline Older calves & $\begin{array}{l}\text { Silage diet } \\
\text { Hay diet }\end{array}$ & $\begin{array}{l}54.7 \\
53.9\end{array}$ & $\begin{array}{l}39.7 \mathrm{D} \\
37.5 \mathrm{D}\end{array}$ & $\begin{array}{l}32.8 \mathrm{E} \\
30.8 \mathrm{E}\end{array}$ & $\begin{array}{l}36.6 \mathrm{E} \\
34.0 \mathrm{E}\end{array}$ & $\begin{array}{l}42.9 \mathrm{E} \\
40.5 \mathrm{E}\end{array}$ \\
\hline $\begin{array}{l}\text { Total silage diet } \\
\text { fed calves }\end{array}$ & & $39.5 \mathrm{~F}$ & $30.6 \mathrm{G}$ & $26.4 \mathrm{H}$ & $29.1 \mathrm{~F}$ & $32.9 \mathrm{~F}$ \\
\hline $\begin{array}{l}\text { Total hay diet } \\
\text { fed calves }\end{array}$ & & $36.3 \mathrm{~F}$ & $27.2 \mathrm{G}$ & $23.3 \mathrm{H}$ & $25.6 \mathrm{~F}$ & $29.6 \mathrm{~F}$ \\
\hline Total younger cal & ves & $26.8 \mathrm{AC}$ & $21.5 \mathrm{AC}$ & $18.2 \mathrm{AC}$ & $19.8 \mathrm{AC}$ & $21.9 \mathrm{AC}$ \\
\hline Total older calves & & $54.4 \mathrm{BC}$ & $38.9 \mathrm{BC}$ & $32.1 \mathrm{BC}$ & $35.7 \mathrm{BC}$ & $42.0 \mathrm{BC}$ \\
\hline
\end{tabular}

Within columns, means bearing the same letters differ significantly (capitals: $P<0.01$. Abbreviations explained in table II.

a linear regression analysis was made to examine the relationship between the 2 variables mentioned (tables $\mathrm{V}, \mathrm{VI}$ ). A marked positive and highly significant relationship was found for LW gains and diameters of all fibres in LD muscle. For the remaining 2 muscles the relationships were less clear. Nevertheless, the relationship between LW gains and fibre diameters seemed to be more pronounced after the withdrawal of milk from the diet (table $V$ vs VI). The interrelationship between fibre diameter and LW gains was in all cases significantly affected by age, and in some cases also by feeding and an interaction between the 2 factors.

\section{Muscle pathologies}

The rearing system applied was not found to induce any pathological changes in the muscle tissue of younger calves. Crosssections of fibres were polygonal. Fibres were closely adjacent to each other, with numerous nuclei beneath sarcolemma and were assembled in bundles separated by thin connective tissue.

In 2 older SD fed calves, some tiny dystrophic fibres were observed. Darkerstained fibres also occurred, with an elliptical cross-section, or wider inter-fibre spaces. 
Table V. Relationship between fibre diameter $(y, \mu \mathrm{m})$ and daily gains of calves $(x, \mathrm{~kg})$ as calculated for the period from 14 days of age to slaughter.

\begin{tabular}{|c|c|c|c|c|c|c|}
\hline \multirow[t]{2}{*}{ Muscle } & \multirow[t]{2}{*}{ Fibre } & \multirow[t]{2}{*}{$\begin{array}{l}\text { Regression } \\
\text { coefficient }\end{array}$} & \multirow{2}{*}{$\begin{array}{l}\text { Regression equation } \\
\text { (given only when } \\
\text { regression coefficient } \\
\text { was significant) }\end{array}$} & \multicolumn{3}{|c|}{$\begin{array}{l}\text { Effect on the relationship between } \\
\text { fibre diameter and } L W \text { gains of: }\end{array}$} \\
\hline & & & & $\begin{array}{l}\text { Age } \\
\text { (A) }\end{array}$ & $\begin{array}{l}\text { Feeding } \\
\quad(F)\end{array}$ & $\begin{array}{l}\text { Interaction } \\
\quad(A \times F)\end{array}$ \\
\hline LD & $\begin{array}{l}\text { FTG } \\
\text { STO } \\
\text { FTO } \\
\text { BO } \\
\text { AT }\end{array}$ & $\begin{array}{r}7.5 x x \\
12.3 x x \\
11.5 x x \\
10.2 x x \\
8.5 x x\end{array}$ & $\begin{array}{l}y=38.01+7.5(x-0.586) \\
y=26.59+12.3(x-0.596) \\
y=21.97+11.5(x-0.592) \\
y=24.20+10.2(x-0.599) \\
y=28.72+8.5(x-0.600)\end{array}$ & $\begin{array}{l}x x \\
x x \\
x x \\
x x \\
x x\end{array}$ & $\begin{array}{l}\text { NS } \\
\text { NS } \\
\text { NS } \\
\text { NS } \\
x\end{array}$ & $\begin{array}{l}x \\
\text { NS } \\
x \\
\text { NS } \\
x x\end{array}$ \\
\hline SM & $\begin{array}{l}\text { FTG } \\
\text { STO } \\
\text { FTO } \\
\text { BO } \\
\text { AT }\end{array}$ & $\begin{array}{l}0.3 \mathrm{NS} \\
5.8 x x \\
5.8 x x \\
0.5 \mathrm{NS} \\
0.3 \mathrm{NS}\end{array}$ & $\begin{array}{l}y=28.02+5.8(x-0.587) \\
y=23.80+5.8(x-0.581)\end{array}$ & $\begin{array}{l}x x \\
x x \\
x x \\
x x \\
x x\end{array}$ & $\begin{array}{l}x \\
\text { NS } \\
x x \\
x x \\
x\end{array}$ & $\begin{array}{l}\text { NS } \\
x x \\
x x \\
x \\
\text { NS }\end{array}$ \\
\hline ST & $\begin{array}{l}\text { FTG } \\
\text { STO } \\
\text { FTO } \\
\text { BO } \\
\text { AT }\end{array}$ & $\begin{array}{l}5.4 x x \\
2.3 \text { NS } \\
0.4 \text { NS } \\
1.7 \text { NS } \\
1.9 \text { NS }\end{array}$ & $y=40.44+5.4(x-0.581)$ & $\begin{array}{l}x x \\
x x \\
x x \\
x x \\
x x\end{array}$ & $\begin{array}{l}N S \\
N S \\
x \\
x x \\
x x\end{array}$ & $\begin{array}{l}\text { NS } \\
x x \\
\text { NS } \\
x x \\
x x\end{array}$ \\
\hline
\end{tabular}

$x$. significant at $P<0.05 ; x x$. significant at $P<0.01 ;$ NS: non significant. Abbreviations explained in table II.

\section{DISCUSSION}

Muscle fibre diameters were affected by both feeding system and calves age, particularly for fibres with glycolytic metabolic capacity (FTG). FTG diameter evidently increased with age.

The changes observed in fibre diameters were found to be related not only to age and (or) feeding, but also to individual muscles. This could be attributed to the various functions of muscles and their nonidentical growth pattern (Richmond and Berg, 1982).

Mean fibre diameters in LD muscle of newborn calves were similar to those reported by Wegner (1983) and Kłosowski and Kłosowski (1988). However, fibre diameters in LD and SD of younger, ie 3month-old calves (feeding systems pooled) were found to be markedly smaller than those reported by Kłosowski and Kłosowska $(1987,1988)$ for calves of a similar age. Again, mean fibre diameter of older animals, ie 10-month-old calves (feeding systems pooled) were smaller than those quoted by Wegner (1983) and Kłosowski and Kłosowska (1988), who reported 49.4 and $47.6 \mu \mathrm{m}$, respectively. Thinner fibres in both younger and older animals, appearing simultaneously with "normal" fibres in newborn calves, could result from the lowconcentrate feeding ( $1 \mathrm{~kg}$ daily) maintained up to the 10th month of life. This was reflected in relatively low daily LW 
Table VI. Relationship between fibre diameter $(y, \mu \mathrm{m})$ and daily gains of calves $(x, \mathrm{~kg})$ as calculated for the period from 42 days of age to slaughter.

\begin{tabular}{|c|c|c|c|c|c|c|}
\hline \multirow[t]{2}{*}{ Muscle } & \multirow[t]{2}{*}{ Fibre } & \multirow[t]{2}{*}{$\begin{array}{l}\text { Regression } \\
\text { coefficient }\end{array}$} & \multirow{2}{*}{$\begin{array}{l}\text { Regression equation } \\
\text { (given only when } \\
\text { regression coefficient } \\
\text { was significant) }\end{array}$} & \multicolumn{3}{|c|}{$\begin{array}{l}\text { Effect on the relationship between } \\
\text { fibre diameter and } L W \text { gains of: }\end{array}$} \\
\hline & & & & $\begin{array}{l}\text { Age } \\
\text { (A) }\end{array}$ & $\begin{array}{l}\text { Feeding } \\
\quad(F)\end{array}$ & $\begin{array}{l}\text { Interaction } \\
\quad A \times F\end{array}$ \\
\hline \multirow[t]{5}{*}{ LD } & FTG. & $10.2 x x$ & $y=38.00+10.2(x-0.557)$ & $x x$ & NS & $x x$ \\
\hline & STO & $10.3 x x$ & $y=26.63+10.3(x-0.566)$ & $x x$ & $x x$ & NS \\
\hline & FTO & $10.1 x x$ & $y=21.95+10.1(x-0.558)$ & $x x$ & NS & $x x$ \\
\hline & $\mathrm{BO}$ & $8.1 \mathrm{xx}$ & $y=24.17+8.1(x-0.565)$ & $x x$ & $x x$ & $x$ \\
\hline & AT & $6.8 x x$ & $y=28.69+6.8(x-0.566)$ & $x x$ & $x x$ & $x x$ \\
\hline \multirow[t]{5}{*}{ SM } & FTG & $3.3 \mathrm{NS}$ & & $x x$ & NS & NS \\
\hline & STO & $4.3 x x$ & $y=27.99+4.3(x-0.557)$ & $x x$ & $x x$ & $x x$ \\
\hline & FTO & $7.9 x x$ & $y=23.80+7.9(x-0.551)$ & $x x$ & $x x$ & $x x$ \\
\hline & BO & $2.1 \mathrm{NS}$ & & $x x$ & $x x$ & $x$ \\
\hline & AT & $2.0 \mathrm{NS}$ & & $x x$ & $x x$ & NS \\
\hline \multirow[t]{5}{*}{ ST } & FTG & $13.3 x x$ & $y=40.35+13.3(x-0.556)$ & $x x$ & $x$ & NS \\
\hline & STO & $4.0 x$ & $y=30.04+4.0(x-0.553)$ & $x x$ & $x$ & $x x$ \\
\hline & FTO & $2.4 \mathrm{NS}$ & & $x x$ & $x$ & NS \\
\hline & BO & $3.3 \mathrm{NS}$ & & $x x$ & $x x$ & $x x$ \\
\hline & AT & $4.4 x x$ & $y=31.79+4.4(x-0.562)$ & $x x$ & $x x$ & $x x$ \\
\hline
\end{tabular}

$x$ : significant at $P<0.05, x x$ : significant at $P<0.01$; NS: non significant. Abbreviations explained in table II.

gains in all calves used. SD fed animals (pooled younger and older animals), which consumed more nutrients per day and had higher weight gains, simultaneously had thicker muscle fibres. On the other hand, Moody et al (1970) working on growing sheep, reported age and body weight at slaughter to be the factors affecting muscle fibre diameter, while LW gains were found to have no statistically confirmed effect.

Relationship between the fibre diameters and LW gains was confirmed by the positive and significant coefficients of regression, more pronounced in LD muscle (tables V, VI). Thus, the differences in fibre diameters between $S D$ and $H D$ calves should be attributed to their different growth rates, arising obviously from a different intake of nutrients (table I). However, this does not seem to exhaust the problem. Although both the younger and older SD fed calves consumed more DM and GE per day than did the HD fed animals, the older SD consumed simultaneously less CP and thus had a considerably lower $\mathrm{CP} / \mathrm{GE}$ ratio. In all cases however, the fibre diameters were larger in the SD group. Moreover, the significant influence of the feeding system on the relationship between fibre diameter and LW gain in cases when the coefficient of regression was non-significant could be interpreted as resulting from some specific traits of the diet 
and not only from the consumption of different quantities of nutrients.

The elliptical and darker stained fibres found in 2 older SD fed calves can be interpreted as being due to super-twitch, which is one of the first manifestations of nutritional myopathia resulting from vitamin E or Se deficiency (Goedegebuure, 1987). According to Pellegrini et al (1982) a longterm maize silage feeding of heifers could be responsible for certain pathologies in the muscle structure.

Under the applied nutritional regime (drastically limited concentrate, forage ad libitum) marked muscle fibre growth took place between the 3rd and 10th month of age. Virtually only the FTG fibres grew from the 2nd week to the 3rd month of life. In this study, rearing calves on a silagebased $v s$ hay-based diet resulted in thicker muscle fibres, the respective differences being significant in LD and ST muscles for each type of fibre; in SM muscle the effect mentioned was not found to be significant either for FTO, or for BO (pooled STO and FTO fibres). Muscle tissue pathologies were found only in 2 out of 5, 10-month-old SD fed calves. This does not indicate any definite detrimental effect of the applied rearing and fattening system on calves' health.

As feeding cattle on silage-only diets is becoming increasingly popular throughout the world, the present study aimed at examining the possible effects of such nutritional regimes on the microstructure of skeletal muscles. The observed differences in muscle fibre growth between HD fed and SD fed animals may arise from differing DM, CP or GE consumption, different CP/GE ratio, or other factors which have not been specified in the present study. However, these differences primarily reflect the applied feeding regime and may be expected in given nutritional conditions. Thus the observed differences in muscular microstructure are also directly connected with the rearing system applied. Results of the linear regression analysis show a close relationship between fibre diameters and LW gains as related to DM intake, but also suggest the possibility of some other specific influence of the diet. Further investigations appear necessary to clarify this point.

\section{ACKNOWLEDGMENTS}

The authors wish to thank $\mathrm{G}$ Zięba and $\mathrm{M}$ Kukaszewicz for helpful advice with the statistical analyses.

\section{REFERENCES}

Bartholomew PW, McLauchlan W, Chestnutt DMB (1981) Effect of unwilted silages and hay, supplemented with different amounts of concentrate, on live-weight gain of calves. Anim Prod 32, 307-313

Beerwinkle DL, Marchello JA, Dryden FD (1979) Histopathological and histochemical characteristics of longissimus and semitendinosus muscles of feedlot and range steers: Abstr 71st ASAS Annu Meet. J Anim Sci 49, suppl 1,212

Bidwell-Porębska K, Piotrowski J, Baranowski A, Krzyżewski J (1987) Nutrient intake, weight gains and certain observations on rumen development in young calves reared on grass silage based diet. Anim Sci Pap Rep 2, $61-76$

Brooke MH (1970) Some comments on neural influence on the two histochemical types of muscle fibres. In: The Physiology and Biochemistry of Muscle as a Food (Briskey EJ, Cassens RG, Marsh BB, eds) The University of Winsconsin Press, Madison, Milwaukee, vol 2, p 131

Chapple DG (1985) Feeding young calves on silage-only diets. Grass Forage Sci 40, 237238

Dubowitz V, Brooke MH, Neville HE (1973) Muscle Biopsy: A Modern Approach. WB Saunders Co Ltd, London 
Goedegebuure SA (1987) Spontaneous primary myopathies in domestic mammals: a review. Vet $Q$ 9, 155-171

Kłosowski B, Kłosowska D (1984) Effect of the fattening intensity on enzymatic activity and size of muscle fibres in Lowland Black-andWhite bulls. Zesz Probl Post Nauk Roln 267, 397-402 (in Polish; English summary)

Kłosowski B, Klosowska D (1987) Histochemical and histological characteristics of the buils' muscles during growth. Proc VIIIth Congr Polish Soc Vet Sci part III, 57-58 (in Polish; English summary)

Kłosowski B, Klosowska D (1988) Age-related changes of the fibre characteristics in longissimus dorsi muscle of Lowland Black-andWhite cattle. Vortrage gehaltete auf dem 4. Morphologie-Kolloquium des Wissenschaftsbereiches Anatomie, Histologie und Embriologie "Wachstum und Postnatale Entwicklung". Karl-Marx Univ, Leipzig, 23 June 1988, 109-113 (in German; English summary)

Kłosowski B, Kłosowska D, Borzuta K (1988) Cechy mikrostruktury mięśnia najdłuższego grzbietu cieląt ciężkich utrzymywanych na diecie z dodatkiem tluszczu. XI Sesja Nau-

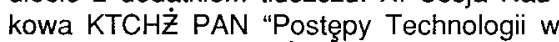
Rozwoju Produkcji ł̇ywności", Szczecin, 1988, 40 (in Polish)

Marsh R (1975) The performance of early weaned calves offered a high dry matter silage supplemented with concentrates or dried grass. Anim Prod 21, 21-30

Marsh R (1976) intake by and performance of early weaned calves offered unwilted or wilted silage supplemented with a cereal and protein concentrate or dried grass. Anim Prod 22, 311-320
Moody WG, Tichenor DA, Kemp JD, Fox KD (1970) Effects of weight, castration and rate of gain on muscle fiber and fat cell diameter in two ovine muscles. J Anim Sci 31, 676-680

Pellegrini N, Renzoni G, Taccini E, Filippi Balestra G, Bagatti E (1982) Experimental evaluation of the visceral and organic dystrophic effects in calves fed with silo-maize only. Note V. Anatomo-histopathological findings in the heart and skeletal muscle. Ann Fac Med Vet Pisa XXXV, $67-72$ (in Italian; English summary)

Piotrowski J, Bidwell-Porębska K, Baranowski A, Krzyżewski J (1988) Intake, growth rate and digestibility in calves fed a restricted amount of concentrate and offered maize silage or grass silage at libitum from the second week of life. Anim Sci Pap Rep 4, 33-52

Richmond RJ, Berg RT (1982) Relative growth patterns of individual muscles in the pig. Can J Anim Sci 62, 575-586

Rumsey TS, Bond J, Berry BW, Hammond AC, Dinius DA (1987) Performance and carcass characteristics of feedlot steers fed all silage diets. Nutr Rep Int 35, 847-862

Seideman SC, Crouse JD (1986) The effect of sex condition, genotype and diet on bovine muscle fiber characteristics. Meat Sci 17, 5572

Wegner J (1983) Post-natal muscle fibre growth in cattle. Akad Landwirtsch DDR, Tagunsbericht No 209, 135-142 (in German; English summary)

Ziegan $J$ (1979) Combinations of enzymehistochemical methods for differentiating fibre types and evaluating the skeletal musculature. Acta Histochem Jena 65, 1, 34-40 (in German; English summary) 